\title{
Collective Narcissism, Anti-Globalism, Brexit, Trump, and the Chinese Juggernaut
}

Russell Belk

York University

Follow this and additional works at: https://digitalcommons.uri.edu/mgdr

Part of the Anthropology Commons, Communication Commons, Economics Commons, Geography Commons, Marketing Commons, Other Business Commons, Political Science Commons, and the Sociology Commons

\section{Recommended Citation}

Belk, Russell (2017) "Collective Narcissism, Anti-Globalism, Brexit, Trump, and the Chinese Juggernaut," Markets, Globalization \& Development Review. Vol. 2: No. 3, Article 2.

DOI: 10.23860/MGDR-2017-02-03-02

Available at: https://digitalcommons.uri.edu/mgdr/vol2/iss3/2

This Article is brought to you for free and open access by DigitalCommons@URI. It has been accepted for inclusion in Markets, Globalization \& Development Review by an authorized editor of DigitalCommons@URI. For more information, please contact digitalcommons-group@uri.edu. 


\section{Markets, Globalization \& Development Review}
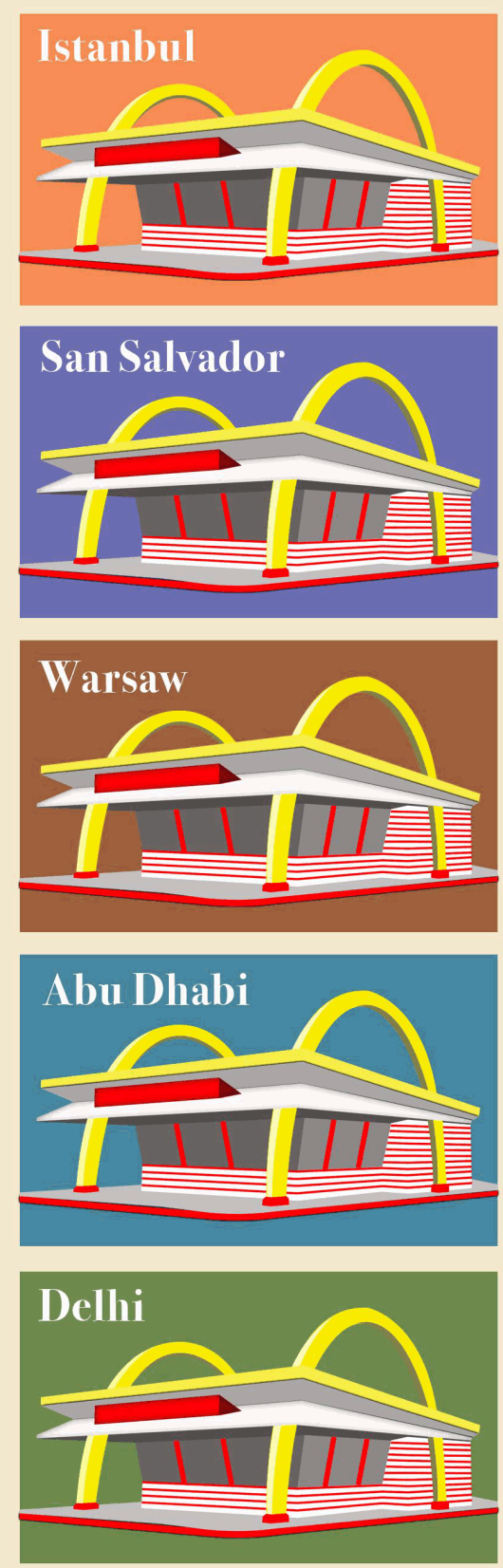
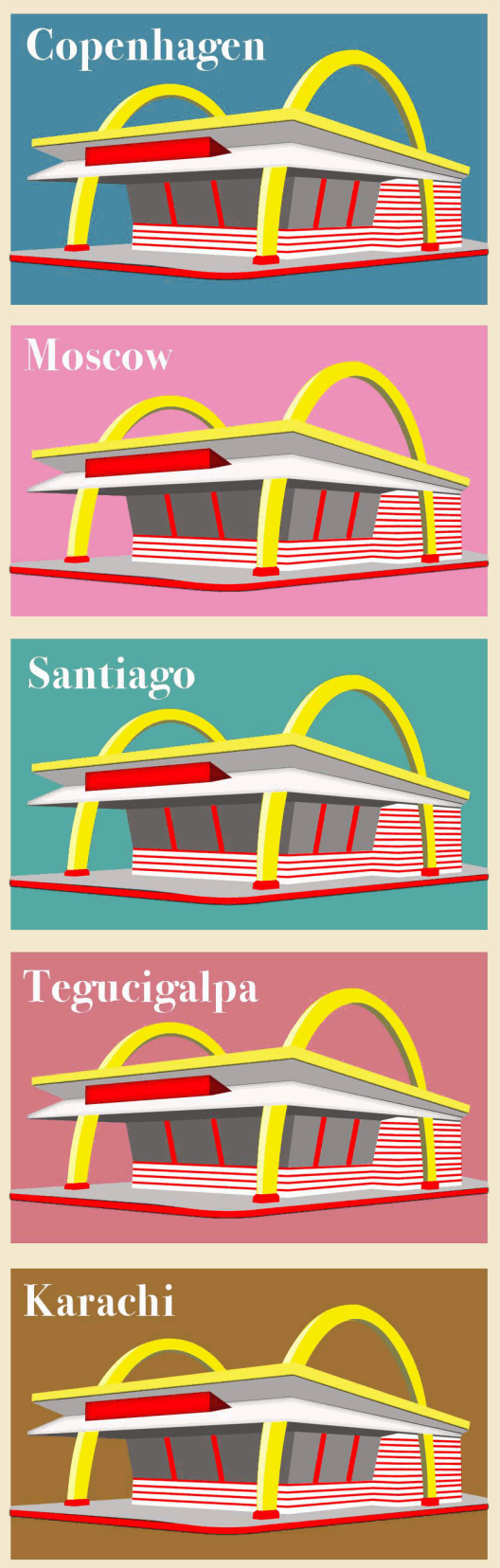
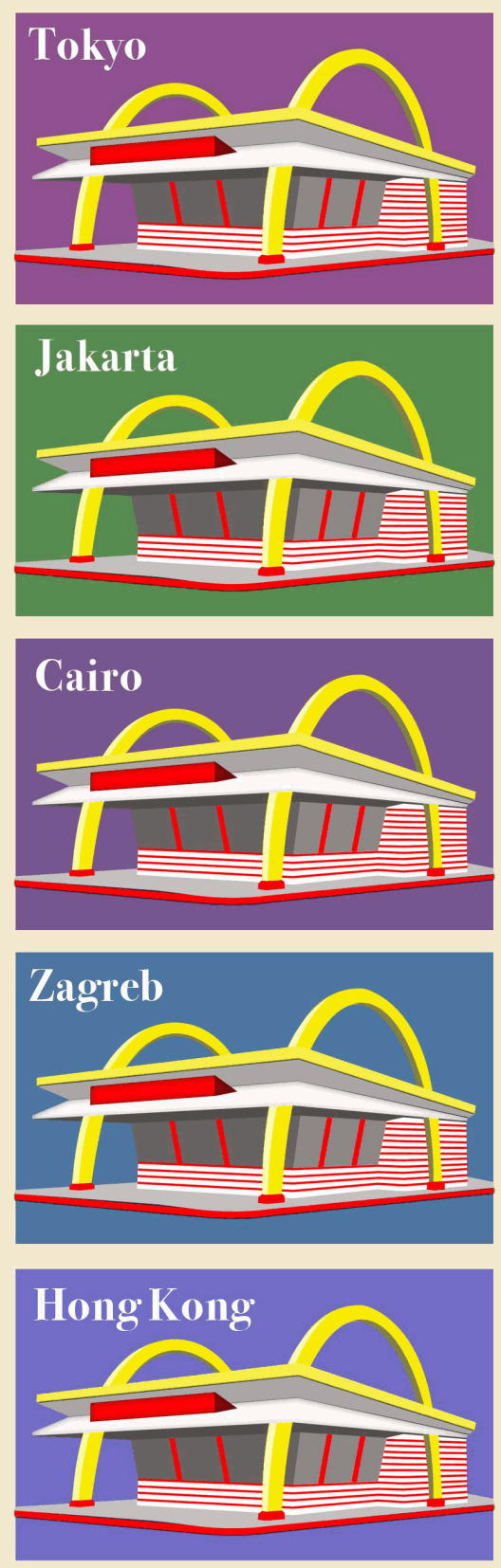

This article is available in Markets, Globalization \& Development Review: https://digitalcommons.uri.edu/mgdr/vol2/ 


\title{
Collective Narcissism, Anti-Globalism, Brexit, Trump, and the Chinese Juggernaut
}

\author{
It has happened before. \\ Strong men put up a city and got \\ a nation together, \\ And paid singers to sing and women \\ to warble: We are the greatest city, \\ the greatest nation, \\ nothing like us ever was (Sandburg 1920).
}

In 2016 Great Britain voted to leave the European Union and the United States elected Donald Trump president. While the slogans of the winning sides, "Take back control" and "Make America great again," differed somewhat, both shared a nationalistic emphasis on "us" versus "them," as well as a revenge motif of restoring former national greatness and putting other nations and peoples in "their place." Both events, as well as contemporary political movements in many other parts of the world, reflect a shift away from global trade, relatively free global flows of immigrants, and acceptance of refugees from war-torn and oppressive regimes. Instead, many of those who supported Brexit and Trump found resonance in arguments that the UK and the US had suffered insults, exploitation, and loss of control at the hands of others such as the European Union, China, Mexico, Islam; and both legal and illegal immigrants. So, the implicit and explicit promises to stem the flow of refugees and illegal immigrants, to erect trade barriers, and to strike back at those portrayed as slighting the UK or the US were seen as opportunities to bring about justice and restore the glory of the motherland.

This is not the first time that immigration issues have been used to drive a wedge between voters and play to xenophobic fears (e.g., Jeong et al. 2011; Riker 1986; Techenor 2002). But in the present cases, those voters to whom these appeals were particularly salient have been characterized as well as demonstrated to be high in collective narcissism. Collective narcissism is defined as "an in-group identification tied to an emotional investment in 'an unrealistic belief about the unparalleled greatness of an ingroup'" (Golec de Zavala et al. 2009, p.1074). Similar to my specification of multiple levels of self, ranging from the individual to the nation (Belk 1988), Golec de Zavala et al. (2009) point to a relationship between individual narcissism and collective narcissism: 
A positive relationship between individual narcissism can be expected because the self-concept consists of personal self and social identities based on the groups to which people belong... Idealization of self may be followed by idealization of ingroups... Collective narcissists may see groups as extensions of themselves and expect everybody to recognize not only their individual greatness but also the prominence of their in-groups (p. 1075).

As Golec de Zavala reports, "collective narcissism very clearly predicted Brexit voting, and it very clearly predicted it thorough the rejection of immigrants and foreign workers" (Resnick 2017). She also found that collective narcissism, together with Republican partisanship, were the strongest predictors of voting for Trump. It is easy to see how Trump's slogans that "China is killing us in trade", "Illegal Mexican immigrants are taking American jobs" and "We don't win anymore" engaged and enraged collective narcissists. Those high in collective narcissism are also hypersensitive to perceived insults to their group. In response to such perceived threats to the greatness of the in-group, the likely response is to feel hostility toward the out-groups that are perceived as undermining or failing to appreciate that in-group's greatness (Golec de Zavala et al. 2016). Should the nation, ethnic group, religion, or other outgroup find misfortune on its own, the feeling is one of Schadenfreude - joy at the suffering of the other (Powell, Smith and Shurtz 2008).

Motivating these feelings of Schadenfreude due to envy and feelings that one's nation has been slighted or maligned, there is an underlying insecurity and self-doubt that fuels collective narcissism. "This 'fragility' makes it different from simply having pride in one's country - in much the same way that [an individual] narcissist is quite different from an individual with healthy self esteem" (Jarrett 2017). This feeling of fragility also makes those high in collective narcissism more apt to believe in conspiracy theories that offer explanations of why "we" are suffering relative to "them," the conspirators. Chichocka et al. (2015) found that those who display collective narcissism feel less in control of their lives. The promises to "take back control" by Trump and those promoting the UK leaving the EU clearly resonate with those with such feelings of lacking control.

There is another element to the argument that collective narcissism helps explain the supporters of anti-globalist and isolationist political shift to the right. It involves the "charismatic leader-follower relationship". Post (1986) split narcissists into "mirror-hungry narcissists" and "ideal-hungry narcissists". Whereas mirror-hungry narcissists seek constant evidence of admiration from others (followers), ideal-hungry narcissists take 
sustenance from the charisma and confidence of a mirror-hungry leader. Leaders like Donald Trump and Adolf Hitler, who are both individual mirror-hungry narcissists, thus provide a compelling solution for idealhungry narcissists, especially when they simplify the solution to the perceived (and touted) weakness of "our" nation as being caused by "them" (other countries, other religions, and other people). For Hitler, the out-groups were the Jews, Romani, the handicapped, and homosexuals; whereas for Trump the scapegoated out-groups are Democrats, the media, Barack Obama, China, Mexico, Islam, blacks, and immigrants (especially those from predominately Muslim nations). The resulting positive attraction between collective narcissism and xenophobic ethnocentrism (Bizumic and Duckitt 2008) helps explain the Brexit vote. Ideal-hungry collective narcissists find succor in blaming the other for all their suffering and voting for mirror-hungry narcissists and their antiimmigrant policies offers what they see as a chance to strike back at those causing their plights. Much of this scapegoating also invokes old Orientalist tropes and newer post-colonial tropes of backward and primitive others (Varman and Belk 2012; Wylie 2009). That "we" should be threatened by inferior "others" only adds to the ego-threat that mirrorhungry narcissists claim they will quash.

It is not necessarily the case that there are more collective narcissists now than there have been in the past, but charismatic leaders have appeared on the scene and mobilized ideal-hungry narcissists at a time when - following the 2008 economic meltdown - economic growth has slowed in much of the world. Due to outsourcing, automation, and the rise of the service economy, the real incomes and economic prospects of the middle-class of the more affluent world have declined. There is also highly visible terrorism afoot in the world that is easily attributed to all Muslims. That is, there is a perfect storm of economic, political, classbased structural shifts; and paranoia-inducing world events that have combined, to result in a reactionary shift to the political right. Because the political solutions offered by narcissistic leaders (Putin, Mugabe, and Erdogan are other examples) do not address the real causes of these conditions, it is unlikely that the shift to the right will be permanent or long lasting. But for the time being it is a reality. If this phenomenon is perceived as a globalization hiccup, there remains a question of how long this fit of hiccups will last. And solutions that do not entail scapegoating will be needed to get out of the present rightist anti-globalism.

Besides narcissism precipitating a political shift, there is also an argument that it perhaps facilitates conspicuous consumption. According to McGregor (2004), because narcissists crave attention, admiration, and 
recognition, they seek to transform themselves via consumption. Because of a grandiose sense of self, they also feel entitled to special treatment, indulgence, and immediate gratification. Their sense of entitlement leads them to consume audaciously and transparently as they feel above moral laws. The fact that members of the struggling middle class who supported Trump do not seem to resent his enormous wealth and over-the-top conspicuous consumption may seem paradoxical. But as a symbol of the nation, what better way to signal strength and superiority than through conspicuous symbols of economic success? Tough talk and brash behavior could well be perceived as showing "them" that "we" are superior and cannot be intimidated. Furthermore, if we aspire to wealth ourselves, whatever envy we may feel toward Trump and his cabinet of billionaires is more likely to be benign rather than malicious (Belk 2011).

The more pernicious aspect of this link between individual narcissism and feelings of entitlement and privilege is the license it is seen to provide to ignoring and trampling upon rights to free speech, freedom on religion, and equality. Coupled with wealth and power, individual narcissists who gain authority are apt to feel impervious to the laws of the land and the rights of those whom they govern. They use their power, wealth, and authority to exercise their will and whims in order to shore up their fragile sense of self. They become bullies and tyrants. Trump, Putin, Erdogan, and Mugabe are all case studies in such exercises of narcissism. The abuses of Reaganism and Thatcherism pale by comparison (Silverman 1986).

These inclinations to conspicuous consumption and bullying inoculated privilege, however, pertain more to the effects of individual narcissism than collective narcissism, although as already noted, the two are often related. Collective narcissism is most likely to erupt where there is a sense of national humiliation. In the case of Turkey such conditions are seen to have emerged from not being allowed to join the EU, while in Portugal it was the austerity measures imposed by the EU and blamed on Germany that led to wanting to retaliate against the Germans (Jarrett 2016, 2017). Perhaps the greatest and most sustained case of national humiliation is China which suffered many such humiliations over the past 100 or more years (Wang 2014). These humiliations include treaty port concessions in the face of British gunboats, lopsided opium trade by the British East India Company, the British sacking of the old Summer Palace, the two failed opium wars and the Boxer Rebellion, the Nanjing Massacre, and other Sino-Japanese war losses and occupations.

The humiliations were real. For instance, in the Sino-Japanese war of 1937-1945, 14 million Chinese died and as many as 100 million 
became displaced refugees. As both Wang (2014) and Schell and Delury (2013) detail, the catechism of a century of humiliation is inculcated in Chinese schoolchildren and occasionally invoked to marshal Chinese consumers to boycott Japanese goods due to memories of Japanese atrocities and the more recent islands disputes in the South China Sea. Furthermore, feelings of deserved revenge for past humiliations are trumpeted with achievements not only in national economic growth, but also the Beijing Olympics, the Shanghai Expo, the Chinese space program, and Chinese investments in commerce, industry, and infrastructure throughout the world.

As these celebrations suggest, rather than a retreat from globalism, in China's case the invocation of collective narcissism and feelings of national humiliation are instead used to justify China's global advance. The goal of becoming a world power has rapidly been achieved in postMao China, and the next goal is building an economic empire within what has been dubbed "The New Silk Road" that is now gathering shape and credibility (Miller 2017). By emphasizing China's past humiliations, China rallies collective narcissistic fever and justifies its successes in the world as merely righting the balances. Such triumphs also bolster the strength of the Chinese Communist Party. And together with its One-China policy it seemingly justifies suppressions of separatism in Tibetan, minority, and Islamic areas of China as well as its objections to recognizing Taiwan as an independent nation. The repatriations of Hong Kong and Macau in the mid- to late-1990s were also portrayed as making up for prior humiliations.

So, while collective narcissism offers an attractive explanation of the shift to the right, isolationism, the retreat from globalism, and resistance to international refugees in Western politics and rhetoric, it also helps explain the growth of despotism in Russia and Turkey, and the expansion of globalism and nationalism in China. Collective narcissism is a powerful card to play in national politics, but it is becoming clear that it can be used for different and even diametrically opposite ends. There is a systematic bias however in that modern-day neo-liberalism tends to favor globalism while modern-day conservativism tends to favor nationalism. This gets into deeper ideological issues of just what nationalism and globalism are taken to represent and how they are to be achieved (Eckhardt, Varman and Dholakia forthcoming; Harvey 2005). But these are topics for another day. 


\section{References}

Belk, Russell (1988), "Possessions and the Extended Self," Journal of Consumer Research, 15 (2), 139-68. https://doi.org/10.1086/209154

Belk, Russell (2011), "Benign Envy," Academy of Marketing Science Review, 1 (December), 117-34. https://doi.org/10.1007/s13162-011$\underline{0018-\mathrm{X}}$

Bizumic, Boris and John Duckitt (2008), "“My Group Is Not Worthy of Me": Narcissism and Ethnocentrism," Political Psychology, 29 (3), 43753. https://doi.org/10.1111/j.1467-9221.2008.00638.x

Cichocka, Aleksandra, Marta Marchlewska, Agnieszka Golec de Zavala and Mateusz Olechowski (2015), "'They will not control us': Ingroup Positivity and Belief in Intergroup Conspiracies," British $\begin{array}{lllll}\text { Journal of Psychology, } 107 & \text { (3), } & \text { 556-76. }\end{array}$ https://doi.org/10.1111/bjop.12158

Eckhardt, Giana, Rohit Varman and Nikhilesh Dholakia (forthcoming), "Iddology and Critical Marketing Studies," in Routledge Companion to Critical Marketing, Mark Tadajewski et al., eds, London: Routledge.

Golec de Zavala, Agnieszka, Aleksandra Cichocka, Roy Eidelson and Nuwan Jajawickreme (2009), "Collective Narcissism and its Social Consequences," Journal of Personality and Social Psychology, 97 (6), 1074-96. https://doi.org/10.1037/a0016904

Golec De Zavala, Agnieszka, Müjde Peker, Rita Guerra, and Tomasz Baran (2016), "Collective Narcissism Predicts Hypersensitivity to Ingroup Insult and Direct and Indirect Retaliatory Intergroup Hostility," European Journal of Personality, 30, 532-51. https://doi.org/10.1002/per.2067

Harvey, David (2005), A Brief History of Neoliberalism. Oxford, UK: Oxford University Press.

Jarrett, Christian (2016), "There's Such a Thing as Collective Narcissism (and it Might Explain a Lot that's Going on at the Moment)," British Psychological Society Research Digest, December 9, (accessed July 1, 2017), [available at https://digest.bps.org.uk/2016/12/09/theres-such-a-thing-ascollective-narcissism-and-it-might-explain-a-lot-thats-going-on-atthe-moment/] 
Jarrett, Christian (2017), "How Collective Narcissism is Directing World Politics: A Little-known Personality Trait may lie Behind the Political Upheaval Across the World," BBC Future, (accessed July 1, 2017), [available at http://bbc.com/future/story/20170303-how-collectivenarcissism-is-directing-world-politics]

Jeong, Gyung-Ho, Gary J. Miller, Camilla Schofield and Itai Sened (2011), "Cracks in the Opposition: Immigration as a Wedge Issue for the Reagan Coalition," American Journal of Political Science, 511-525. https://doi.org/10.1111/j.1540-5907.2011.00516.x

McGregor, Sue (2004), "Consumer Entitlement, Narcissism, and Immoral Consumption," (accessed July 1, 2017), [available at https://www.kon.org/hswp/archive/mcgregor 1.doc]

Miller, Tom (2017), China's Asian Dream: Empire Building along the New Silk Road, London: Zed Books.

Powell, Caitlin A. J., Richard H. Smith, and David R. Shurtz (2008), "Schadenfreude Caused by an Envied Person's Pain," in Envy: Theory and Research, Richard H. Smith, ed. Oxford: Oxford University Press, 148-64.

Post, Jerrold (1986), "Narcissism and the Charismatic Leader-Follower Relationship," Political Psychology, 7 (4), $675-88$. http://dx.doi.org/10.2307/3791208

Resnick, Brian (2017), "How 'Collective Narcissism" Helps Explain the Election of Trump," Vox, January 4, (accessed July 1, 2017), [available at http://www.vox.com/science-andhealth/2017/1/4/14106088/collective-narcissism-trump-brexitpsychology]

Riker, William T. (1986), The Art of Political Manipulation. New Haven, CT, USA: Yale University Press.

Schell, Orville and John Delury (2013), Wealth and Power: China's Long March to the Twenty-first Century, New York: Random House.

Sandburg, Carl (1920), "Four Preludes to Playthings on the Wind," in Smoke and Steel, London: Jonathan Cape, 75-80.

Silverman, Debora (1986), Selling Culture: Bloomingdales, Diana Vreeland, and the New Aristocracy of Taste in Regan's America, New York: Pantheon. 
Tichenor, Daniel J. (2002), Dividing Lines: The Politics of Immigration Control in America. Princeton, NJ, USA: Princeton University Press.

Varman, Rohit and Russell Belk (2012), "Consuming Post-Colonial Shopping Malls," Journal of Marketing Management, 28 (February), 62-84. http://dx.doi.org/10.1080/0267257X.2011.617706

Wang, Zheng (2014), Never Forget National Humiliation: Historical Memory in Chinese Politics and Foreign Relations, New York: Columbia University Press.

Wylie, Lesley (2009), Colonial Tropes and Postcolonial Tricks: Rewriting the Tropics in the Novela de la Selva, Liverpool: Liverpool University Press. 